\title{
Removing New Growth Reduces Fruiting in Cranberry
}

Teryl R. Roper ${ }^{1}$ and John S. Klueh ${ }^{2}$

Department of Horticulture, University of Wisconsin-Madison, 1575 Linden

Drive, Madison, WI 53706

\section{Additional index words. Vaccinium macrocarpon, carbon partitioning}

Abstract. The sources of photosynthate for fruit growth in cranberry (Vaccinium macrocarpon Ait.) can be spatially partitioned as new growth, old leaves and woody stems, or adjoining uprights. New growth, l-year-old leaves, or both were removed at the time of fruit set and following fruit set. Removing new growth at the time of fruit set reduced fruit set, fruit count, and yield. Removing old leaves at fruit set generally did not reduce fruit set, fruit count, or yield. Removing both often had an additional effect. Removing new leaves after fruit set did not affect fruit set or count, but did reduce fruit size. Removing old leaves after fruit set did not reduce fruit set, fruit count, or size. These data suggest that new growth is an important source of photosynthate for fruit set.

The commercially grown cranberry is a low-growing broadleaf evergreen vine. Fruit are borne on short vertical shoots called uprights. Flowers open acropetally on uprights over 2 to 4 weeks, depending on the weather. Basal flowers are more likely to set fruit than those in upper positions that open later (Baumann and Eaton, 1986). Flowers are borne on the basal portion of current-season growth and have newly produced acropetal leaves and one-year-old basipetal leaves. Potential sources of current-season photosynthate to support fruit growth in cranberry can be spatially partitioned into acropetal leaves (current-season growth), basipetal leaves (one-year-old growth), or leaves on adjacent uprights on the same runner. In addition, some photosynthate may come from stored reserves in perennial portions of the vines.

Eaton and Kyte (1978) showed that yield in cranberry was most limited by the number of fruiting uprights per ground area and percent fruit set. Fruit set can be limited by inadequate pollination (Birrenkott and Stang, 1989) or by competition for limited resources (Birrenkott and Stang, 1990). Fruit set and flower initiation have been shown to be affected by carbohydrate concentration in other temperate woody plants (Goldschmidt et al., 1985; Scholefield et al., 1985; Worley, 1979).

Roper et al. (1992) showed that fruit set in cranberry was reduced most if new growth acropetal to fruit was removed in early to midJuly during fruit set. when acropetal growth was removed earlier or later than this, fruit set was unaffected or affected slightly. Severely shading (93\% shade) cranberry vines immediately after bloom reduced fruit set and nonstructural carbohydrate content of vines (T.R.R., unpublished data).

Received for publication 12 Apr. 1993. Accepted for publication 26 Aug. 1993. The cost of publishing this paper was defrayed in part by the payment of page charges. Under postal regulations, this paper therefore must be hereby marked advertisement solely to indicate this fact.

'Assistant Professor.

${ }^{2}$ Assistant Researcher.
This research was undertaken to ascertain the relative importance of new leaves, oneyear-old leaves, and adjacent tissues for supporting cranberry fruit set and growth.
The research was conducted in mature beds of 'Searles' cranberries growing at DuBay Cranberry Co., near Stevens Point, Wis., and Gottschalk Cranberries near Wisconsin Rapids, Wis., in 1991 and 1992. The Gottschalk marsh did not receive the late treatment in 1991. Treatments were imposed after the lower flowers had opened and pinhead-size fruit were visible. Uprights were selected that had at least two fruit developing when the following treatments were imposed: 1) no leaves removed; 2) 1-year-old leaves basipetal to fruit removed; 3) new growth acropetal to fruit (leaves and stem) removed; and 4) both new growth and 1-year-old leaves removed. These same treatments were also imposed $\approx 2$ weeks later, after fruit set was complete. Each upright was tagged with a plastic label, and individual uprights were examined later in the season for regrowth of tissue. Each treatment consisted of 10 replications with five uprights per replication. In September, before commercial harvest, all tagged uprights were cut and taken to the laboratory. For each upright, the number of flowers (persistent pedicels) and fruit were

Table 1. Effect of removing various tissues at the time of fruit set on percent flowers producing fruit and yield of 'Searles' cranberry growing at DuBay Cranberry Co., Stevens Point, Wis. $(n=10)$.

\begin{tabular}{|c|c|c|c|c|}
\hline \multirow[b]{2}{*}{$\begin{array}{l}\text { Tissue } \\
\text { removed }\end{array}$} & \multirow{2}{*}{$\begin{array}{c}\text { Flowers } \\
\text { producing } \\
\text { fruit } \\
(\%)\end{array}$} & \multirow[b]{2}{*}{$\begin{array}{l}\text { Fruit } \\
\text { count }\end{array}$} & \multicolumn{2}{|c|}{ Wt (g) } \\
\hline & & & $\begin{array}{l}\text { Total } \\
\text { fruit }^{2} \\
\end{array}$ & $\begin{array}{r}\text { Mean/ } \\
\text { fruit } \\
\end{array}$ \\
\hline . & \multicolumn{2}{|c|}{1992} & & \\
\hline None & $52 \mathrm{a}$ & $2.1 \mathrm{a}$ & $2.35 \mathrm{a}$ & 1.07 \\
\hline Basipetal leaves & $48 \mathrm{a}$ & $1.9 \mathrm{a}$ & $1.99 \mathrm{ab}$ & 1.01 \\
\hline \multicolumn{5}{|l|}{ Acropetal leaves } \\
\hline and stems & $36 \mathrm{~b}$ & $1.4 \mathrm{~b}$ & $1.51 \mathrm{bc}$ & 0.98 \\
\hline Both & $25 \mathrm{c}$ & $0.9 \mathrm{~b}$ & $1.19 \mathrm{c}$ & 0.95 \\
\hline Significance & $* *$ & $* *$ & $* *$ & NS \\
\hline \multicolumn{5}{|c|}{1991} \\
\hline None & $46 a$ & $1.8 \mathrm{a}$ & $2.41 \mathrm{a}$ & 1.34 \\
\hline Basipetal leaves & $41 \mathrm{a}$ & $1.6 \mathrm{a}$ & $2.09 \mathrm{a}$ & 1.32 \\
\hline \multicolumn{5}{|l|}{ Acropetal leaves } \\
\hline and stems & $34 \mathrm{~b}$ & $1.1 \mathrm{~b}$ & $1.38 \mathrm{~b}$ & 1.22 \\
\hline Both & $20 \mathrm{c}$ & $0.8 \mathrm{c}$ & $1.26 \mathrm{~b}$ & 1.23 \\
\hline Significance & $* *$ & $* *$ & $* *$ & NS \\
\hline
\end{tabular}

${ }^{2}$ Per upright.

Ns $* *$ Nonsignificant or significant at $P<0.01$, respectively.

Table 2. Effect of removing various tissues at the time of fruit set on percent flowers producing fruit and yield of 'Searles' cranberry growing at Gottschalk Cranberry Co., Wisconsin Rapids, Wis. $(\mathrm{n}=10)$.

\begin{tabular}{|c|c|c|c|c|}
\hline \multirow[b]{2}{*}{$\begin{array}{l}\text { Tissue } \\
\text { removed }\end{array}$} & \multirow{2}{*}{$\begin{array}{c}\text { Flowers } \\
\text { producing } \\
\text { fruit } \\
(\%) \\
\end{array}$} & \multirow[b]{2}{*}{$\begin{array}{l}\text { Fruit } \\
\text { count }\end{array}$} & \multicolumn{2}{|c|}{$W t(g)$} \\
\hline & & & $\begin{array}{l}\text { Total } \\
\text { fruit }^{z}\end{array}$ & $\begin{array}{c}\text { Mean/ } \\
\text { fruit } \\
\end{array}$ \\
\hline \multicolumn{5}{|c|}{1992} \\
\hline None & $46 \mathrm{a}$ & $1.8 \mathrm{a}$ & $2.21 \mathrm{a}$ & $1.27 \mathrm{a}$ \\
\hline Basipetal leaves & $35 \mathrm{~b}$ & $1.2 \mathrm{~b}$ & $1.42 \mathrm{~b}$ & $1.04 \mathrm{~b}$ \\
\hline \multicolumn{5}{|l|}{ Acropetal leaves } \\
\hline and stems & $34 b$ & $1.2 \mathrm{~b}$ & $1.69 \mathrm{~b}$ & $1.14 \mathrm{ab}$ \\
\hline Both & $21 \mathrm{c}$ & $0.8 \mathrm{c}$ & $1.26 \mathrm{~b}$ & $1.02 \mathrm{~b}$ \\
\hline Significance & $* *$ & $* *$ & $* *$ & $*$ \\
\hline \multicolumn{5}{|c|}{1991} \\
\hline None & $55 \mathrm{a}$ & $1.9 \mathrm{a}$ & $2.55 \mathrm{a}$ & $1.39 \mathrm{a}$ \\
\hline Basipetal leaves & $39 \mathrm{~b}$ & $1.4 \mathrm{~b}$ & $1.91 \mathrm{~b}$ & $1.10 \mathrm{~b}$ \\
\hline \multicolumn{5}{|l|}{ Acropetal leaves } \\
\hline and stems & $28 \mathrm{c}$ & $1.1 \mathrm{c}$ & $1.73 \mathrm{~b}$ & $1.43 \mathrm{a}$ \\
\hline Both & $20 \mathrm{c}$ & $0.8 \mathrm{~d}$ & $1.54 \mathrm{~b}$ & $1.34 \mathrm{a}$ \\
\hline Significance & $* *$ & $* *$ & $* *$ & $* *$ \\
\hline
\end{tabular}


counted and percent fruit set calculated. Fruit from each upright were weighed and mean weight per fruit calculated.

Data were analyzed as a completely randomized design by analysis of variance. Mean were separated by LSD following a significant F test.

\section{Results and Discussion}

The four treatments imposed in these experiments eliminated individual sources of carbohydrates for the support of fruit set or development. When new leaves were removed, fruit could be supported by 1-year-old leaves or adjoining uprights; when 1-year-old leaves were removed, fruit could be supported by new leaves or adjoining uprights; when leaves of both ages were removed, fruit could only be supported by adjoining uprights. In each case there could have been some support by stored reserves.

Removing the previous season's leaves basipetal to fruit at the time of fruit set did not reduce the percentage of flowers producing fruit, fruit count per upright, total fruit weight per upright, or mean fruit weight at DuBay (Table 1), but did cause a reduction at Gottschalk (Table 2). Removing leaves and stems acropetal to the fruit at fruit set reduced the percentage of flowers producing fruit, fruit count per upright, and total fruit weight per upright in both locations both years (Tables 1 and 2). However, the mean weight of individual fruit was not affected when currentseason's leaves were removed. When leaves both acropetal and basipetal to fruit were removed there was often, but not always, a slight additional reduction in fruit count per upright, percentage of flowers producing fruit, and total fruit weight per upright. Mean fruit weigh was reduced only in 1992 at Gottschalk (Table 2). Differences in a given variable between the two marshes are likely caused by differences in management between the two properties.

When leaves were removed after fruit had set and were beginning to develop, results were different. Once the fruit had set, they did not abort, but were carried through to maturity even if leaves were removed. The percentage of flowers producing fruit was unaffected by late removal of any leaves (Tables 3 and 4). Fruit count per upright also stayed mostly stable. However, mean fruit weight was reduced when all leaves were removed in 1992 at both locations and when acropetal leaves were removed at DuBay in 1992 (Tables 3 and 4). Mean weight per fruit was reduced when both types of leaves were removed in 1991 . Total fruit weight per upright was reduced at DuBay in 1991 and 1992 if both types of leaves were removed and in 1992 if acropetal leaves were removed. Since the percentage of flowers producing fruit was not reduced, reductions in total fruit weight per upright were due to reduced individual-fruit size.

These data suggest that when sources of photosynthate are removed early, the plant compensates for the loss by setting fewer fruit, but those that are produced are of normal size. When leaves are removed after fruit set. mean fruit size is reduced. There was no evidence of fruit abortion caused by leaf removal after fruit set, as based on fruit count (Tables 3 and 4).

Fruit set in cranberry has previously been shown to be more sensitive to loss of leaf tissue at the time of fruit set than to leaf removal earlier or later (Roper et al., 1992). Nonstructural carbohydrates drop to their lowest seasonal level beginning at early flowering and continuing on through fruit set (Birrenkott et al., 1991; Hagidimitriou, 1993). Leaf removal at the time of lowest carbohydrate concentration would further limit carbohydrate resources available to developing fruit, and fewer fruit would develop. Birrenkott and Stang (1990) found that if early opening flowers in lower positions on an upright were removed early (at preblossom or late blossom stages), fruit set of the remaining upper flowers was higher than if flower removal was delayed until after fruit set or if no flowers or fruit were removed. When competing fruit were removed, remaining fruit were more likely to set and develop. Both approaches to studying competition for limited resources (leaf removal or flower removal) support the same conclusion, i.e., that the fruit set period is critical to fruit development in cranberry.

The rate of net photosynthesis of new leaves is roughly double that of 1-year-old leaves (Hagidimitriou, 1993). It is not surprising then

Table 3. Effect of removing various tissues after fruit set on percent flowers producing fruit and yield of 'Sales' cranberry growing at DuBay Cranberry Co., Stevens Point, Wis. $(\mathrm{n}=10)$.

\begin{tabular}{|c|c|c|c|c|}
\hline \multirow[b]{2}{*}{$\begin{array}{l}\text { Tissue } \\
\text { removed }\end{array}$} & \multirow{2}{*}{$\begin{array}{c}\text { Flowers } \\
\text { producing } \\
\text { fruit } \\
(\%) \\
\end{array}$} & \multirow[b]{2}{*}{$\begin{array}{l}\text { Fruit } \\
\text { count }\end{array}$} & \multicolumn{2}{|c|}{ Wt $(\mathrm{g})$} \\
\hline & & & $\begin{array}{l}\text { Total } \\
\text { fruit }^{z}\end{array}$ & $\begin{array}{c}\text { Mean/ } \\
\text { fruit }\end{array}$ \\
\hline \multicolumn{5}{|c|}{1992} \\
\hline None & 61 & $2.3 \mathrm{a}$ & $2.45 \mathrm{a}$ & $1.07 \mathrm{a}$ \\
\hline Basipetal leaves & 63 & $2.3 \mathrm{a}$ & $2.34 \mathrm{a}$ & $1.01 \mathrm{ab}$ \\
\hline \multicolumn{5}{|l|}{ Acropetal leaves } \\
\hline and stems & 55 & $1.9 \mathrm{~b}$ & $1.38 \mathrm{c}$ & $0.74 \mathrm{c}$ \\
\hline Both & 55 & $2.1 \mathrm{ab}$ & $1.85 \mathrm{~b}$ & $0.86 \mathrm{bc}$ \\
\hline Significance & $*$ & NS & $* *$ & $* *$ \\
\hline \multicolumn{5}{|c|}{1991} \\
\hline None & 52 & 2.2 & $2.80 \mathrm{a}$ & $1.28 \mathrm{a}$ \\
\hline Basipetal leaves & 52 & 2.3 & $2.82 \mathrm{a}$ & $1.30 \mathrm{a}$ \\
\hline \multicolumn{5}{|l|}{ Acropetal leaves } \\
\hline and stems & 55 & 2.1 & $2.60 \mathrm{a}$ & $1.22 \mathrm{a}$ \\
\hline Both & 50 & 2.0 & $2.02 \mathrm{~b}$ & $1.05 \mathrm{~b}$ \\
\hline Significance & NS & NS & $* *$ & $* *$ \\
\hline
\end{tabular}

${ }^{2}$ Per upright.

ss $, *, *$ Nonsignificant or significant at $P \leq 0.05$ or 0.01 , respectively.

Table 4. Effect of removing various tissues after fruit set on percent flowers producing fruit and yield of 'Searles' cranberry growing at Gottschalk Cranberry Co., Wisconsin Rapids, Wis. $(\mathrm{n}=10)$.

\begin{tabular}{|c|c|c|c|c|}
\hline \multirow[b]{2}{*}{$\begin{array}{l}\text { Tissue } \\
\text { removed } \\
\end{array}$} & \multirow{2}{*}{$\begin{array}{c}\text { Flowers } \\
\text { producing } \\
\text { fruit } \\
(\%)\end{array}$} & \multirow[b]{2}{*}{$\begin{array}{l}\text { Fruit } \\
\text { count }\end{array}$} & \multicolumn{2}{|c|}{ Wt $(\mathrm{g})$} \\
\hline & & & $\begin{array}{l}\text { Total } \\
\text { fruit }^{z}\end{array}$ & $\begin{array}{r}\text { Mean/ } \\
\text { fruit } \\
\end{array}$ \\
\hline \multicolumn{5}{|c|}{1992} \\
\hline None & 51 & 1.8 & 1.74 & $1.00 \mathrm{a}$ \\
\hline Basipetal leaves & 47 & 1.6 & 1.67 & $1.01 \mathrm{a}$ \\
\hline \multicolumn{5}{|l|}{ Acropetal leaves } \\
\hline and stems & 47 & 1.7 & 1.88 & $1.04 \mathrm{a}$ \\
\hline Both & 50 & 1.6 & 1.49 & $0.85 \mathrm{~b}$ \\
\hline Significance & NS & NS & NS & $*$ \\
\hline
\end{tabular}

${ }^{2}$ Per upright.

ss, " "Nonsignificant or significant at $P \leq 0.05$. that removing new leaves would have a pronounced effect on fruit set. Dickmann and season progressed, younger needles became more important. Reader (1978) determined hat although 1-year-old leaves of three bog intilarates than new leaves, they were imporing new growth. New growth of balsam fir Abies balsamea (L.) Mill.] was supported by photosynthate produced in the current year, rather than from stored reserves (Little, 1970). -year-old cranberry leaves also appear to the season before new leaves are fully developed and photosynthetically competent (Hagidimitriou, 1993)

The full effect of leaf removal on fruit set and size may not have been evident in this research if net photosynthesis had been enhanced in response to partial defoliation, as has been found in other species (Baysdorfer Bassham, 1985; Hodgkinson, 1974; Layne the shoot apex also may have affected the results by altering the concentration of plant ormones within an upright.

Taken in aggregate, this research supports the hypothesis that fruit set is resource-limited in cranberry and the limitation is likely photowere impor (1968) found that old Pinus needles 
synthate. New leaves acropetal to fruit appear to be the most important source of carbohydrates for fruit set.

\section{Literature Cited}

Baumann, T.F. and G.W. Eaton. 1986. Competition among berries on the cranberry upright. J. Amer. Soc. Hort. Sci. 111:869-872.

Baysdorfer, C. and J.A. Bassham. 1985. Photosynthate supply and utilization in alfalfa. A developmental shift from a source to a sink limitation of photosynthesis. Plant Physiol. 77:313-317.

Birrenkott, B.A., C.A. Henson, and E.J. Stang. 1991 Carbohydrate levels and the development of fruit in cranberry. J. Amer. Soc. Hort. Sci. 116:174-178.

Birrenkott, B.A. and E.J. Stang. 1989. Pollination and pollen tube growth in relation to cranberry fruit development. J. Amer. Soc. Hort. Sci. 114:733-737.
Birrenkott, B.A. and E.J. Stang. 1990. Selective flower removal increases cranberry fruit set. HortScience 25:12261228.

Dickmann, D.I. and T.T. Kozlowski. 1\%8. Mobilization by Pinus resinosa cones and shoots of $\mathrm{C}^{14}$-photosynthate from needles of different ages. Amer. J. Bet. 55:900-906.

Eaton, G.W. and T.R, Kyte. 1978. Yield component analysis in the cranberry. J. Amer. Soc. Hort. Sci. 103:578-583.

Goldschmidt, E.E., N. Aschkenazi, Y. Herzano, A.A. Schafer, and S.P. Monselise. 1985. A role for carbohydrate levels in the control of flowering in citrus. Scientia Hort. 26:159-166.

Hagidimitriou, M. 1993. Carbohydrate partitioning and photosynthesis in cranberry. PhD Diss., Univ. of Wisconsin, Madison.

Hodgkinson, K.C. 1974. Influence of partial defoliation on photosynthesis, photorespiration and transpiration by lucerne leaves of different ages. Austral. J. Plant Physiol. 1:561-578.

Layne, D.R. and J.A. Flore. 1992. Photosynthetic compensation to partial leaf area reduction in sour cherry. J. Amer. Soc. Hort. Sci. 117:279286.

Little, C.H.A. 1970. Derivation of the springtime starch increase in balsam fir (Abies balsamea). Can. J. Bet. 48:1995-1999.

Reader, R.J. 1978. Contribution of overwintering leaves to the growth of three broad-leaved, evergreen shrubs belonging to the Ericaceae family. Can. J. Bet. 56:1248-1261.

Roper, T. R., E.J. Stang, and G.M. Hawker. 1992. Early season leaf removal reduces fruit set and size in cranberry. HortScience 27:75.

Scholefield, P. B., M. Sedgley, and D.McE. Alexander. 1985. Carbohydrate recycling in relation to shoot growth, floral initiation and development and yield in avocado. Scientia Hort. 25:99-110.

Wolk, J.O., D.W. Kretchman, and D.J. Ortega, Jr. 1983. Response of tomato to defoliation. J. Amer. Soc. Hort. Sci. 108:536-540.

Worley, R.E. 1979. Fall defoliation date and seasonal carbohydrate concentration of pecan wood tissue. J. Amer. Soc. Hort. Sci. 104: 195-199. 